\title{
Making maintenance of the case-mix system user friendly
}

\author{
C Østerballe Pedersen \\ From 26th Patient Classification Systems International (PCSI) Working Conference \\ Munich, Germany. 15-18 September 2010
}

\section{Introduction}

Maintaining and developing a case-mix system can be a complicated matter requiring years of experience, as well as extensive knowledge of the framework behind it. Because it is a complex task to maintain and develop the system, unintended effects or mistakes may arise from time to time. In addition, it can be difficult to communicate to users of the system what is required before a patient can be assigned to a specific case-mix group. To address these issues, a tool called VAGS (Visually Assisted Grouping System) has been developed in Denmark.

\section{Methods}

VAGS is based on a graphical framework in which the developer, by a simple point-and-click, can make changes and add new groups to an existing case-mix system. A number of validation rules have been implemented in the tool. This guarantees that if a mistake is made while maintaining the case-mix system, it will be immediately discovered. Furthermore, the tool is fed with valid procedure and diagnosis codes, thus guaranteeing that only valid codes can be used.

Since the maintenance of the case-mix system is made graphically, a visual exposition is available at all times to be published to users of the system. From VAGS, the visual exposition can be published directly to a web page. Also, the graphical approach to maintaining the case-mix system helps to ensure full transparency since the whole system is presented to the users.

\section{Results}

VAGS will result in better quality in the case-mix system. It makes maintenance of the system readily accessible and ensures full transparency for hospital owners and other users of the system. Feedback from hospital owners on case-mix changes made in the spring 2010

Health Economics, Ministry of Interior and Health, Copenhagen, Denmark was of much higher quality and more tangible than it was in the years before.

\section{Conclusions}

The tool is expected to increase the reliability of the case-mix system. It has already proven useful in presenting changes in the case-mix system to hospital owners and improving validation of the changes. An add-on to VAGS is planned which will allow cost-impact analysis to be made as soon as a change or update is made.

To sum up, VAGS is:

- User friendly and readily accessible to developers

- Ensures transparency in exposition of the case-mix system

- Makes it easy to perform cost-impact analysis

- Brings the quality of the case-mix system to a new and higher level

Published: 6 October 2010

doi:10.1186/1472-6963-10-S2-A10

Cite this article as: Pedersen: Making maintenance of the case-mix system user friendly. BMC Health Services Research 2010 10(Suppl 2):A10.

Submit your next manuscript to BioMed Central and take full advantage of:

- Convenient online submission

- Thorough peer review

- No space constraints or color figure charges

- Immediate publication on acceptance

- Inclusion in PubMed, CAS, Scopus and Google Scholar

- Research which is freely available for redistribution

Submit your manuscript at www.biomedcentral.com/submit
Biomed Central 